\title{
Caddo Ceramic Vessel Sherd Assemblages from Sites in the Sabine River Basin, Harrison County, Texas
}

Timothy K. Perttula

Follow this and additional works at: https://scholarworks.sfasu.edu/ita

Part of the American Material Culture Commons, Archaeological Anthropology Commons, Environmental Studies Commons, Other American Studies Commons, Other Arts and Humanities Commons, Other History of Art, Architecture, and Archaeology Commons, and the United States History Commons

Tell us how this article helped you.

This Article is brought to you for free and open access by the Center for Regional Heritage Research at SFA ScholarWorks. It has been accepted for inclusion in Index of Texas Archaeology: Open Access Gray Literature from the Lone Star State by an authorized editor of SFA ScholarWorks. For more information, please contact cdsscholarworks@sfasu.edu. 


\section{Caddo Ceramic Vessel Sherd Assemblages from Sites in the Sabine River Basin, Harrison County, Texas \\ Creative Commons License \\ (c) (1) (8)}

This work is licensed under a Creative Commons Attribution-NonCommercial 4.0 International License 


\section{Caddo Ceramic Vessel Sherd Assemblages from Sites in the Sabine River Basin, Harrison County, Texas}

Timothy K. Perttula

\section{Introduction}

Ancestral Caddo ceramic vessel sherd assemblages from three sites in the Sabine River basin in Harrison County, Texas, are documented in this article. The sherds from the three sites ( $\mathrm{n}=272$ total sherds) are held in the collections of the Gregg County Historical Museum in Longview, Texas.

Sites

The three ancestral Caddo sites with ceramic vessel sherd assemblages are in the vicinity of Darco, Texas, in the Spring Creek and Potters Creek drainages of the Sabine River basin (Figure 1). These sites were investigated by Buddy C. Jones between ca. 1954-1963.

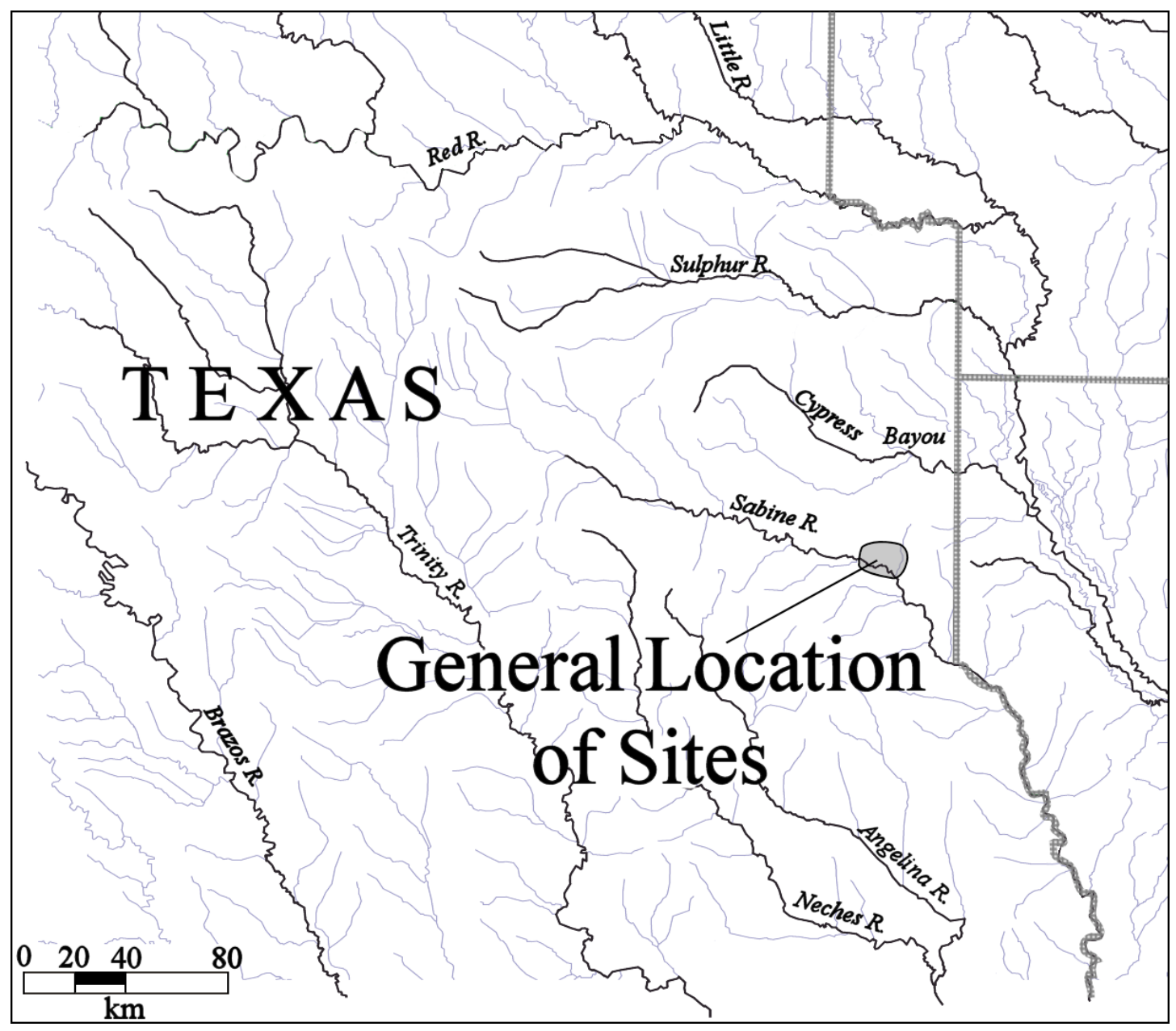

Figure 1. General locations of the ancestral Caddo sites discussed in this article. 


\section{Darco Site (HC 32)}

The Darco site (HC 32 in Jones' catalog system) is on Spring Creek 0.5 miles south of the Darco coal mine plant. Spring Ceek is a small stream that drains south into the Sabine River a few kilometers to the south (see Perttula and Skiles 1987:Figure 2); the community of Darco is ca. $1 \mathrm{~km}$ east of the coal mine plant. The ceramic vessel sherds from the Darco site were collected by Buddy C. Jones sometime before 1954 .

The ceramic vessel sherd assemblage includes sherds from plain ware, utility ware, and fine ware (Table 1). Almost 90 percent of the sherds are from vessels tempered solely with grog; another 7.3 percent are from vessels tempered with grog and bone. The remaining 3.1 percent-sherds from utility ware vessels - are tempered with crushed and burned bone.

Table 1. Ceramic vessel sherds by ware and temper in the Darco site ceramic assemblage.

\begin{tabular}{lcccc}
\hline Ware & Grog & $\begin{array}{c}\text { Temper Categories } \\
\text { Grog-Bone }\end{array}$ & Bone \\
\hline Plain & 13 & 1 & - & 14 \\
Utility & 61 & 6 & 3 & 70 \\
Fine & 12 & - & - & 12 \\
\hline Totals & 86 & 7 & 3 & 96 \\
\hline
\end{tabular}

The 82 decorated sherds in the assemblage from the Darco site are predominantly from utility wares (85.4 percent). The fine wares (14.6 percent of the decorated sherds) are all from grog-tempered vessels (see Table 1). The decorated sherds are from two different cultural components, one dating to Formative to Early Caddo period times and the other to after ca. A.D. 1200, and most likely after ca. A.D. 1400, being affiliated with the Pine Tree Mound community in the Sabine River basin (see Fields and Gadus 2012).

The Formative to Early Caddo period utility wares have incised (21.4 percent of the utility wares), incised-punctated (15.7 percent), and punctated (20.0 percent) decorative elements (Table 2). These are from Davis Incised, Dunkin Incised, Kiam Incised and/or Weches Fingernail Impressed (Figure 2c), Crockett Curvilinear Incised (Figure 2b), and Pennington Punctated-Incised (Figure 2a) vessels. Two sherds have incised lines with accented ends, and may be from French Fork Incised, var. Laborde (Figure 2d) and var. French Fork (Figure 3b) vessels from Lower Mississippi Valley potters (see Brown 1998:14, 24; Phillips 1970:Figure 29b).

Table 2. Decorative methods and elements in the utility ware and fine ware sherds from the Darco site.

\begin{tabular}{llll}
\hline Decorative method and elements & Rim & Body & $N$ \\
\hline
\end{tabular}

\section{Utility ware}

\section{Appliqued-Punctated}

straight appliqued ridge-adjacent tool punctated row

Brushed

diagonal brushed marks

opposed brushed marks

parallel brushed marks

vertical brushed marks 
Table 2. Decorative methods and elements in the utility ware and fine ware sherds from the Darco site, cont.

Decorative method and elements

$\operatorname{Rim}$

Body

$\mathrm{N}$

Brushed-Appliqued

parallel brushed marks-straight appliqued ridge

parallel brushed marks-straight appliqued fillet

Brushed-Incised

parallel brushed-incised marks and lines

parallel brushed-overlying curvilinear incised lines

parallel brushed-overlying straight incised line

Brushed-Punctated

horizontal brushed marks-tool punctated row below

the lip

horizontal brushed marks-tool punctated row through

the brushing under the lip

parallel brushed marks-fingernail punctated row through

the brushing

tool punctated row above vertical brushed marks

Incised

cross-hatched incised lines

horizontal incised line below lip

$2+$ horizontal incised lines

horizontal-vertical incised lines

horizontal-vertical incised lines and incised line with

accented end

opposed incised lines

parallel incised lines

short incised lines with accented ends

straight incised line

Incised-Punctated

closely-spaced parallel incised lines on either side of tool punctated row

curvilinear incised lines-semi-circular tool punctated-

filled zone

curvilinear incised lines-tool punctated-filled zone

curvilinear incised zone filled with tool punctations

diagonal incised lines and adjacent fingernail punctated

row

horizontal incised lines-tool punctated row under the lip

horizontal incised lines with tool punctations between

lines

horizontal incised lines-tool punctated-filled zones

parallel incised lines and tool punctated-filled zone

parallel incised lines-tool punctated row

Punctated

fingernail punctated rows

linear tool punctated rows

opposed tool punctated rows

tool punctated rows

$\begin{array}{lll}- & 1 & 1 \\ - & 1 & 1 \\ & & \\ - & 14 & 14 \\ - & 1 & 1 \\ - & 1 & 1\end{array}$

14

1

1

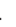

(n)


Table 2. Decorative methods and elements in the utility ware and fine ware sherds from the Darco site, cont.

\begin{tabular}{llll}
\hline Decorative method and elements & Rim & Body & $\mathrm{N}$ \\
\hline
\end{tabular}

\section{Fine ware}

\section{Engraved}

concentric circular engraved lines with open pendant triangle el.

cross-hatched engraved semi-circle el.

curvilinear engraved lines with excised pendant

triangle el.

diagonal engraved lines

diagonal opposed engraved lines with excised triangle el.

hatched semi-circle engraved el.

$2+$ horizontal engraved lines

horizontal engraved zone with vertical hatched lines

horizontal-diagonal opposed engraved lines

opposed curvilinear engraved el.

parallel engraved lines

vertical engraved lines

Totals

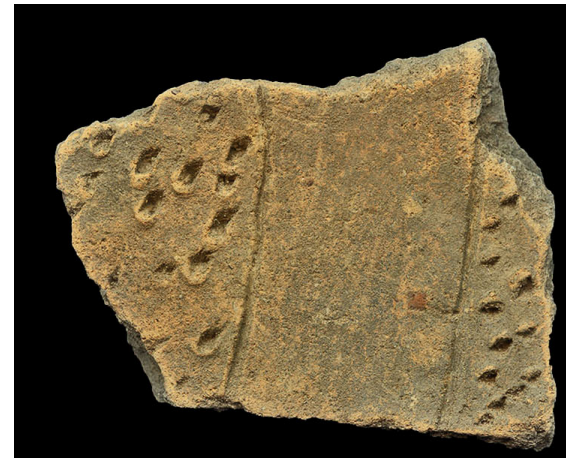

A

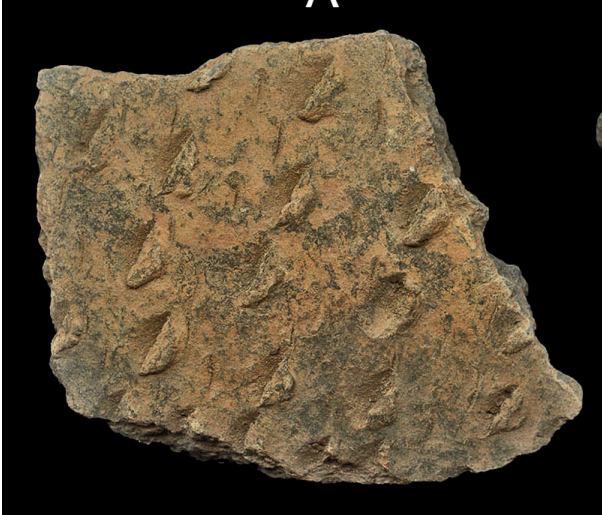

C
12

270

-
-
-
1
1
-
1
1
-
-
-
-

1

1

1

1

1

1

1

1

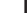

1

1

1

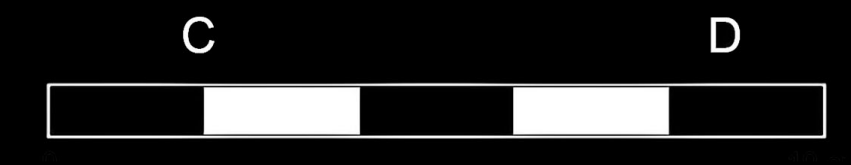

\section{B}

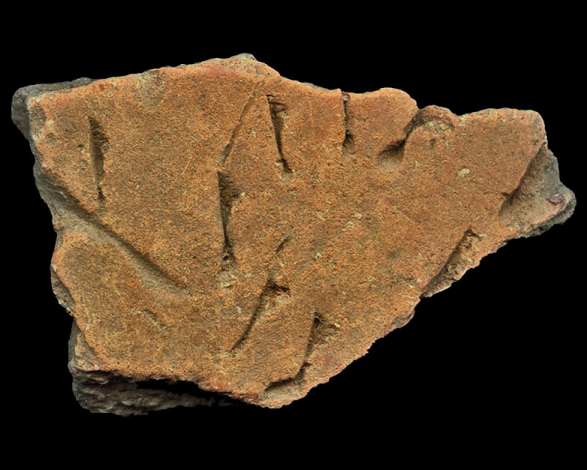

D

Figure 2. Selected decorated utility ware sherds from the Darco site, Harrison County, Texas. Image provided by Julian A. Sitters. 


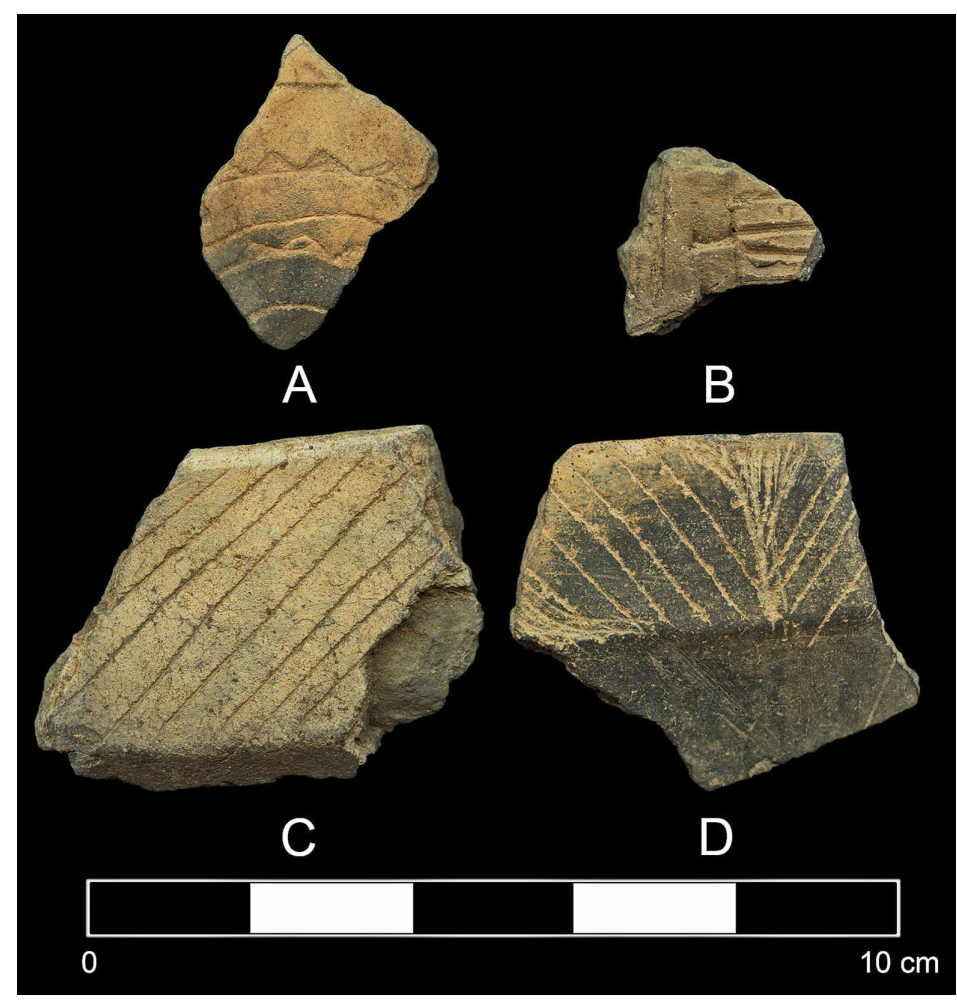

Figure 3. French Fork Incised and engraved fine ware sherds from the Darco site, Harrison County, Texas. Image provided by Julian A. Sitters.

The utility ware sherds from the later component include rim and body sherds with appliquedpunctated (1.4 percent of the utility wares), brushed (10.0 percent), brushed-appliqued ( 2.9 percent), brushed-incised (22.9 percent), and brushed-punctated (5.7 percent) decorative elements (see Table 2). These are from Bullard Brushed and Pease Brushed-Incised vessels. None of the fine ware sherds can be specifically associated with this later ancestral Caddo component at the Darco site.

Two of the fine ware sherds from the Darco site are definitely from Holly Fine Engraved carinated bowls: one grog-tempered rim sherd with fine diagonal engraved lines, and the other with diagonal opposed engraved lines divided by large excised triangle elements (Figure 3c-d). Two other sherds with pendant triangle elements have circular or curvilinear engraved lines (Figure 3a; see Table 2). One rim sherd with 2+ horizontal engraved lines may be from a Hickory Engraved vessel. One bottle sherd has opposed curvilinear engraved lines.

In addition to the ceramic vessel sherds from the two Caddo components, there are four Formative to Early Caddo period ceramic vessels in the Buddy Jones Collection from an excavated burial feature at the Darco site. These are a Weches Fingernail Impressed jar, a Crockett Curvilinear Incised bowl, a Holly Fine Engraved carinated bowl, and a Spiro Engraved bottle (Perttula and Nelson 2018).

\section{Darco Mound Site or Old Man's Site (HC 33)}

Buddy Jones worked at the Darco Mound site or the Old Man's site (HC 33) in December 1960. He described it as being 2 miles southeast of the aforementioned Darco site, which places the site in the Potter's Creek valley a few miles south of the Resch site (41HS16) (Webb et al. 1969:Figure 1). 
About 76 percent of the sherds from the Darco Mound site are from grog-tempered vessels, and the remainder (all plain ware) are from bone-tempered vessels (Table 3). The few decorated utility and fine ware sherds are from grog-tempered vessels.

Table 3. Ceramic vessel sherds by ware and temper in the Darco Mound site ceramic assemblage.

\begin{tabular}{lccc}
\hline Ware & $\begin{array}{c}\text { Temper Categories } \\
\text { Grog }\end{array}$ & Bone & N \\
\hline Plain & 8 & 5 & 13 \\
Utility & 6 & - & 6 \\
Fine & 2 & - & 2 \\
\hline Totals & 16 & 5 & 21 \\
\hline
\end{tabular}

The eight decorated sherds in the small decorated sherd assemblage from the Darco Mound site include utility ware (75 percent) and fine ware (25 percent) (Table 4). The utility ware sherds have appliqued (16.7 percent), brushed-incised (33 percent), incised (33 percent), and incised-punctated (16.7 percent) decorative elements from Formative to Early Caddo period (ca. A.D. 850-1200) Dunkin Incised and Pennington Punctated-Incised (Figure 4a) vessels. The brushed-incised sherds in the assemblage indicate that the Darco Mound site was also occupied after ca. A.D. 1200, when brushed utility ware jars began to be regularly made and used by ancestral Caddo peoples. The Caddo peoples living at the Darco Mound site are likely affiliated with the Late Caddo period Titus phase Pine Tree Mound (41HS15) community in this part of the Sabine River basin (Fields and Gadus 2012:Figure 9.10).

Table 4. Decorative methods and elements in the utility ware and fine ware sherds from the Darco Mound site.

$\begin{array}{llll}\text { Decorative method and elements } & \text { Rim } & \text { Body }\end{array}$

\section{Utility ware}

\section{Appliqued}

straight appliqued ridge

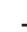

Brushed-Incised

parallel brushed-incised marks and lines

\section{Incised}

diagonal opposed incised lines

horizontal-vertical incised lines

Incised-Punctated

diagonal incised lines and triangular-shaped area filled with tool punctations

\section{Fine ware}

\section{Engraved}

curvilinear engraved line with hatched pendant semi-

circle and excised triangle el.

diagonal engraved lines and excised triangle el.

Totals

(2)




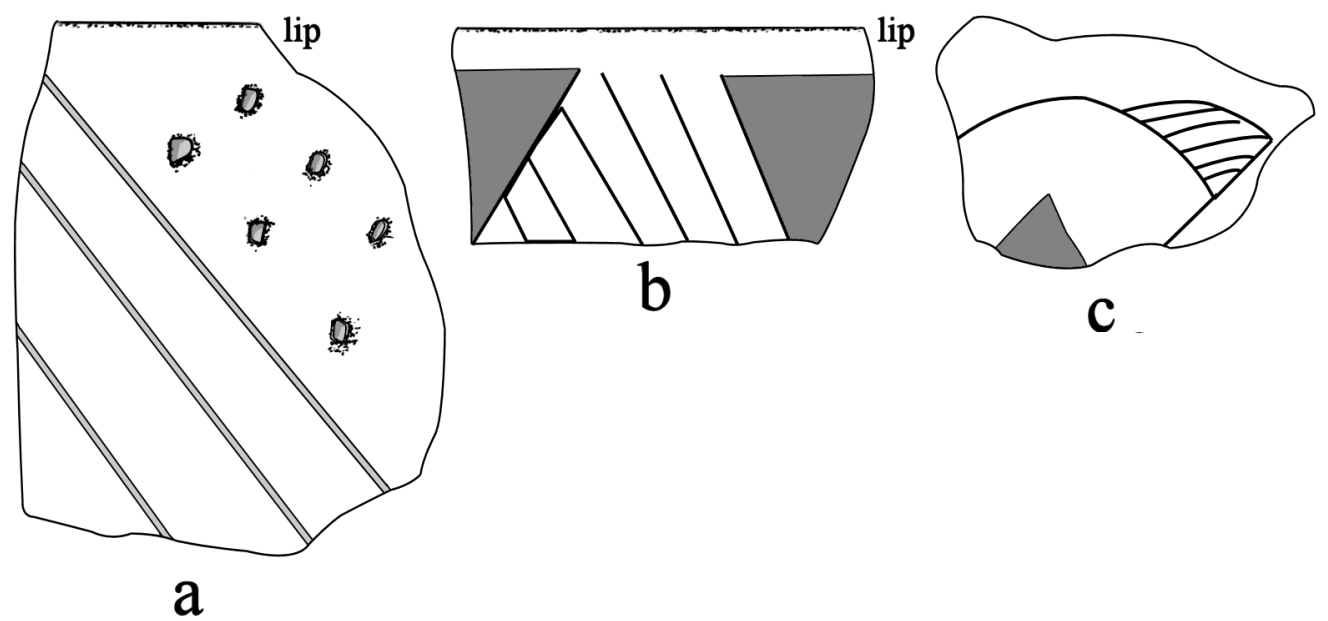

Figure 4. Selective decorative elements in utility ware and fine ware sherds from the Darco Mound site.

One of the fine ware sherds in the Darco Mound site assemblage is from a grog-tempered Holly Fine Engraved carinated bowl (see Figure $4 \mathrm{~b}$ ). The sherd has a set of diagonal engraved lines with upper and lower excised triangles. The other fine ware sherd may also be from a Holly Fine Engraved vessel as it has a portion of a large excised triangle (see Figure 4c), as well as diagonal and curvilinear engraved lines and a hatched semi-circle element.

\section{Coal Mine Site}

Buddy Jones investigated the Coal Mine site in Darco, Texas, in 1963. A more specific location relative to the Darco Mine and stream drainages is not available in Jones' notes on file at the Gregg County Historical Museum.

The ceramic vessel sherd assemblage from the Coal Mine site is primarily represented by sherds from grog-tempered plain ware, utility ware, and fine ware vessels. Approximately 90 percent of the sherds (ranging from 88-93 percent by ware) are from grog-tempered vessels (Table 5). Another 7.3 percent are sherds from grog-bone-tempered vessels, and 2.6 percent are sherds from bone-tempered vessels.

Table 5. Ceramic vessel sherds by ware and temper in the Coal Mine site ceramic assemblage.

\begin{tabular}{lllll}
\hline Ware & Grog & $\begin{array}{c}\text { Temper Categories } \\
\text { Grog-Bone }\end{array}$ & Bone & N \\
\hline Plain & 63 & 7 & 2 & 72 \\
Utility & 66 & 4 & 1 & 71 \\
Fine & 7 & - & 1 & 8 \\
\hline Totals & 136 & 11 & 4 & 151 \\
\hline
\end{tabular}

The 79 decorated sherds in the Coal Mine site ceramic sherd assemblage are from utility ware (90 percent) and fine ware (10 percent) (see Table 5), almost all from grog-tempered vessels. As with the two other sites in the Darco area discussed in this article, sherds from brushed (23.9 percent), brushed-incised 
(18.3 percent), and brushed-incised-punctated (2.8 percent) vessels are common in the utility wares from the Coal Mine site (Table 6), indicating that the site was occupied after ca. A.D. 1200 or even later during the Titus phase. None of the fine ware engraved sherds from the site can be associated with the post-A.D. 1200 settlement there.

Table 6. Decorative methods and elements in the utility ware and fine ware sherds from the Coal Mine site.

\begin{tabular}{llll}
\hline Decorative method and elements & Rim & Body & $N$ \\
\hline
\end{tabular}

\section{Utility ware}

\section{Brushed}

horizontal-diagonal brushed marks

overlapping brushed marks

parallel brushed marks

$\begin{array}{lll}1 & - & 1 \\ - & 1 & 1 \\ - & 15 & 15\end{array}$

\section{Brushed-Incised}

overlapping brushed-incised marks and lines

parallel brushed-incised marks and lines

parallel brushed marks-overlying straight incised line

$\begin{array}{lll}- & 1 & 1\end{array}$

$\begin{array}{ccc}- & 11 & 11\end{array}$

$\begin{array}{cll}- & 1 & 1\end{array}$

\section{Brushed-Incised-Punctated}

diagonal incised lines-horizontal brushed marks-tool punctated row parallel brushed-incised marks and lines with tool punctated row between brushing zones

\section{Incised}

diagonal incised lines

diagonal opposed incised lines

closely-spaced horizontal incised lines

incised lip line

parallel incised lines

straight incised line

1

\section{Incised-Punctated}

circular incised zone with linear tool punctations diagonal incised line-tool punctated-filled zone diagonal incised lines-tool punctated row under lip horizontal incised lines-tool punctated row between lines

\section{Punctated}

fingernail punctated rows single fingernail punctation tool punctated row $\begin{array}{lll}1 & 3 & 4\end{array}$

$\begin{array}{ll}1 & 2\end{array}$

$-\quad 8$
$-\quad 8$ 
Table 6. Decorative methods and elements in the utility ware and fine ware sherds from the Coal Mine site, cont.

\begin{tabular}{llll}
\hline Decorative method and elements & Rim & Body & $\mathrm{N}$ \\
\hline
\end{tabular}

Fine ware

Engraved

concentric semi-circular engraved lines and excised semi-circle el.

curvilinear engraved line

diagonal engraved lines-excised triangle el.

excised triangle el.

horizontal-diagonal engraved lines

straight engraved line

vertical engraved lines with hatched triangle el.

Totals

10

$1-1$

$\begin{array}{lll}- & 1 & 1 \\ - & 1 & 1 \\ - & 1 & 1 \\ - & 1 & 1 \\ - & 2 & 2 \\ - & 1 & 1\end{array}$

69

The remainder of the utility wares from the Coal Mine site have incised (28.2 percent), incisedpunctated (7.0 percent), and punctated (19.7 percent) decorative elements (see Table 6). These include a Dunkin Incised rim with diagonal opposed incised lines (Figure 5a), band punctated sherds (i.e., horizontal incised lines with a tool punctated row between the lines), and Crockett Curvilinear Incised and Pennington Punctated-Incised vessel sherds with circular or triangular zones filled with punctations. One Coles Creek Incised, var. unspecified rim sherd is in the assemblage; this rim has a single incised lip line.

Three carinated bowl sherds in the Coal Mine site assemblage are from Holly Fine Engraved vessels. The first has concentric semi-circular engraved lines and an excised semi-circle element (see Figure 5b), while the second has diagonal engraved lines adjacent to a large excised triangle element (see Figure 5c). The third sherd has a large excised triangle element. A fourth sherd, probably from another Holly Fine Engraved vessel, has vertical engraved lines with upper hatched triangle elements (see Figure 5d).

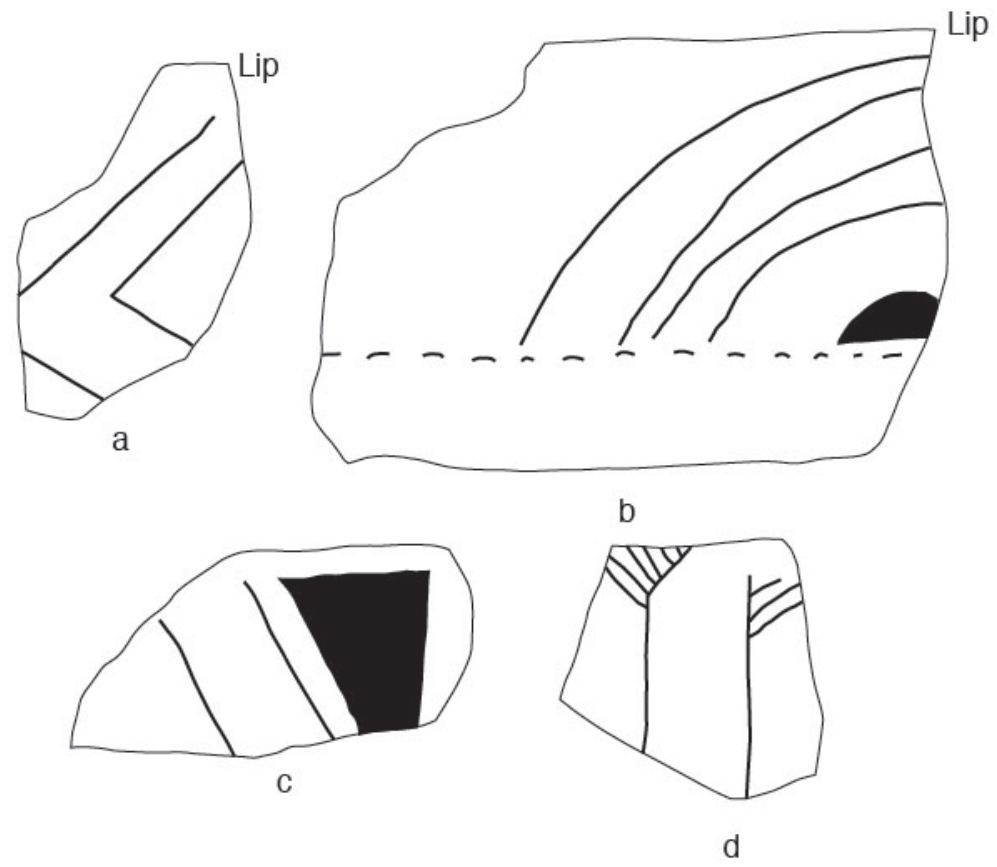

Figure 5. Selected decorative elements on utility ware and fine ware sherds from the Coal Mine site, Harrison County, Texas. 


\section{Summary and Conclusions}

Buddy Jones investigated the Darco, Darco Mound, and Coal Mine sites on Spring and Potter's Creek in the Sabine River basin in Harrison County, Texas, in the 1950s and early 1960s, and obtained from each modest assemblages of plain ware, utility ware, and fine ware sherds; four vessels from a burial feature were obtained from the Darco site (see Perttula and Nelson 2018). Analysis and documentation of these sherds, now in the collections of the Gregg County Historical Museum in Longview, Texas, indicate that the sites have Formative to Early Caddo (ca. A.D. 850-1200) sherds from Crockett Curvilinear Incised, Davis Incised, Dunkin Incised, Hickory Engraved, Holly Fine Engraved, Pennington Punctated-Incised, and Weches Fingernail Impressed ceramic vessels. The Darco and Coal Mine sites have sherds from Lower Mississippi Valley Coles Creek Incised or French Fork Incised types (see Brown 1998).

Well represented at each of the three sites are sherds from post-A.D. 1200 to post-A.D. 1400 brushed, brushed-appliqued, brushed-incised, brushed-incised-punctated, and brushed-punctated utility ware vessels, including sherds from Bullard Brushed and Pease Brushed-Incised types. No fine ware sherds from the sites can be associated with the utility wares. It is probable that these utility wares represent ceramics made and used by ancestral Caddo peoples that were part of the Pine Tree Mound site (41HS15) community in this part of the Sabine River basin (see Fields and Gadus 2012).

\section{Acknowledgments}

Thanks to Patti Haskins of the Gregg County Historical Museum for the opportunity to analyze these Buddy Jones sherd collections held by the museum. Thanks also to Julian A. Sitters for the scan of decorated sherds from the Darco site; Lance Trask prepared the other figures in the article.

\section{References Cited}

Brown, I. W.

1998 Decorated Pottery of the Lower Mississippi Valley: A Sorting Manual. Mississippi Archaeological Association and Mississippi Department of Archives and History, Jackson.

Fields, R. C. and E. F. Gadus (editors)

2012 Archeology of the Nadaco Caddo: The View from the Pine Tree Mound Site (41HS15), Harrison County, Texas. 2 Vols. Reports of Investigations No. 164. Prewitt \& Associates, Inc., Austin.

Perttula, T. K. and B. Nelson

2018 Continued Documentation of Ancestral Caddo Ceramic Vessels from East Texas Caddo Sites in the Buddy Jones Collection at the Gregg County Historical Museum. Journal of Northeast Texas Archaeology 79 (this volume).

Perttula, T. K. and B. D. Skiles

1987 Cultural Resources Survey of the Darco Mine Permit Extension Area, Harrison County, Texas. Reports of Investigations No. 58. Prewitt and Associates, Inc., Austin.

Philips, P.

1970 Archaeological Survey in the Lower Yazoo Basin, Mississippi, 1949-1955. Papers of the Peabody Museum of Archaeology and Ethnology 60. Harvard University, Cambridge.

Webb, C. H., F. E. Murphey, W. G. Ellis, and H. R. Green

1969 The Resch Site, 41HS16, Harrison County, Texas. Bulletin of the Texas Archeological Society 40:3106. 


\title{
Analysis of a Surface Collection from the Walnut Branch Site (41CE47), Cherokee County, Texas
}

\author{
Timothy K. Perttula and Kevin Stingley
}

\section{Introduction}

The Walnut Branch site (41CE47) is one of three ancestral Caddo sites located about six miles southwest of the city of Rusk, along Walnut Branch in the Box's Creek valley in the Neches River basin (Figure 1). Box's Creek is a generally southern-flowing tributary to the Neches River, and enters the river not far to the west-northwest of the George C. Davis site (41CE19).

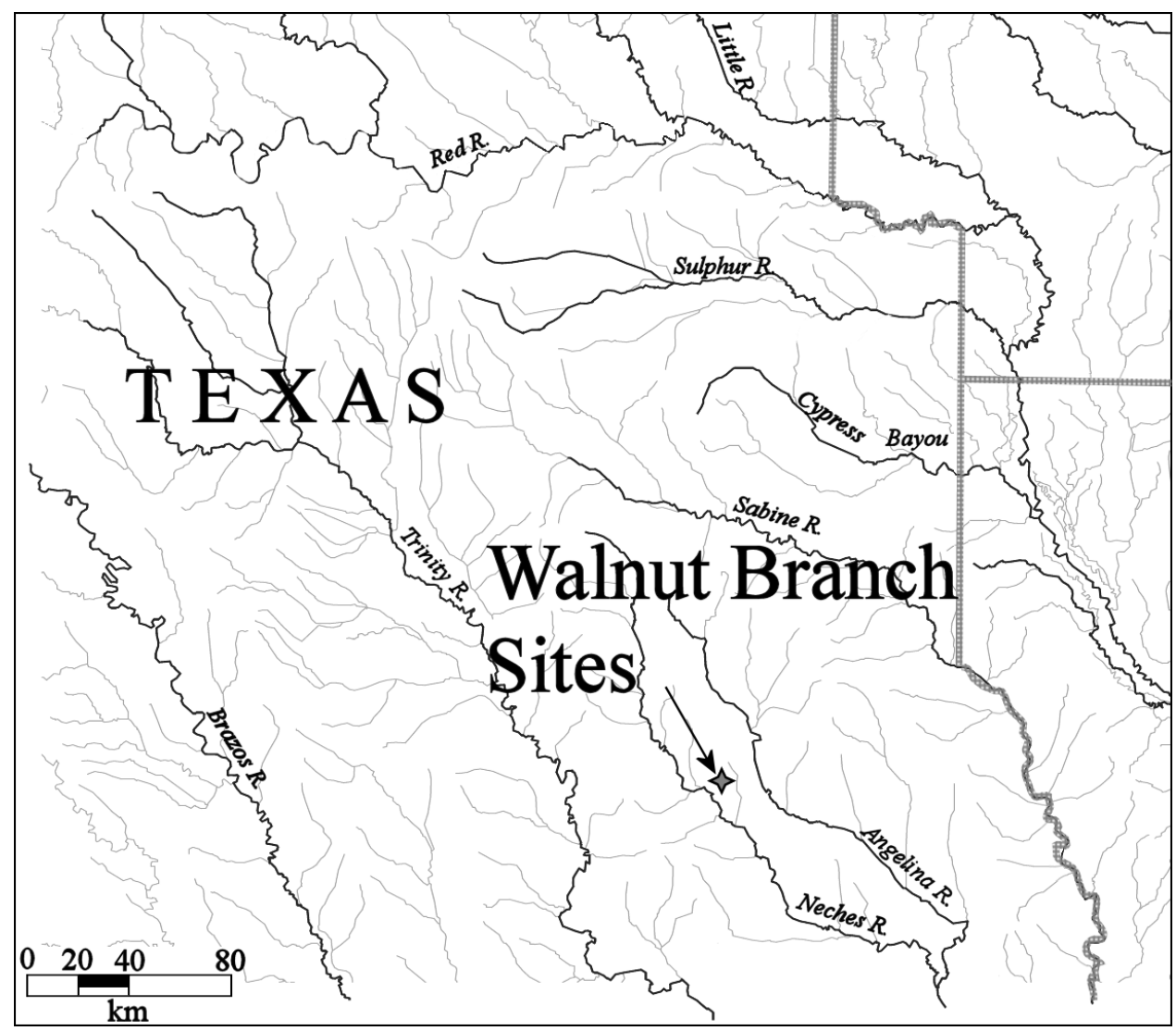

Figure 1. The general location of the Walnut Branch site and nearby Ross I and Ross II sites in East Texas.

In 2017, Stingley completed an intensive program of shovel testing across a large field and floodplain north of Walnut Branch and east of Box's Creek in the area of the Walnut Branch site. He also obtained a substantial collection of ancestral Caddo ceramic vessel sherds from the Walnut Branch stream bed just below the Walnut Branch site and the later recognized Ross I site. The intensive shovel testing demonstrated that the large pasture that contains the Walnut Branch site also contains two other spatially related ancestral 
Caddo sites (Ross I, 41CE485 and Ross II, 41CE486) to the west and northeast, respectively, of the Walnut Branch site (Perttula and Stingley 2017:Figure 2). The intensive shovel testing completed at the Walnut Branch site established that it is approximately $110 \mathrm{x} 100 \mathrm{~m}$ in size, or ca. 2.7 acres (Perttula and Stingley 2017:Figure 3). A total of 72 shovel tests on the landform had cultural materials.

The recovered artifacts - principally ceramic vessel sherds - from the three sites indicate that the sites were occupied primarily in the Historic Caddo Allen phase (dating after ca. A.D. 1680), and are part of a Historic Caddo community related to the Neche cluster. The Neche cluster of ceramic vessel sherd assemblages also includes several Allen phase Historic Caddo sites on Bowles Creek and on the Neches River (41CE291) (Perttula and Stingley 2017:Table 22).

In early 2018, Stingley obtained a substantial surface collection of artifacts from the Walnut Branch site, primarily ceramic vessel sherds. The analysis of these artifacts is the subject of this article.

\section{Artifacts from the 2018 Surface Collection}

The 2018 surface collections came from the Walnut Branch site area as well as along the Walnut Branch stream bed. It includes 163 plain or decorated ceramic vessel sherds, one decorated elbow pipe bowl sherd, and a chipped stone flake tool.

\section{Ceramic Vessel Sherds}

The ceramic vessel sherd assemblage includes plain ware, utility ware, and fine ware (Table 1). The plain to decorated sherd ratio is 0.77 , little different than the ratio of 0.71 from the larger assemblage discussed by Perttula and Stingley (2017:Table 13). The sherds are from vessels tempered with grog (46.6 percent), grog-bone (3.7 percent), grog-hematite (42.3 percent), grog-bone-hematite (1.8 percent), and bone-hematite (5.5 percent). More than 94 percent of the sherds have grog as a temper, either as the sole temper or in combination with bone or hematite, and 11.0 percent are from vessels with bone temper. Approximately 50 percent of the ceramic vessel sherds have crushed pieces of hematite. There is little difference between the 2018 surface collection sherds and the assemblage previously discussed by Perttula and Stingley (2017:Table 19) from the Walnut Branch site, in that 95.6 percent of the vessel sherds $(n=480)$ in the latter had grog temper, 13.1 percent had bone temper, and 39.4 percent had hematite temper.

Table 1. Wares and tempers represented in the ceramic vessel sherds from the surface collection at the Walnut Branch site (41CE47).

\begin{tabular}{|c|c|c|c|c|c|c|}
\hline \multirow[b]{2}{*}{ Ware } & \multirow[b]{2}{*}{$\mathrm{G}^{*}$} & \multicolumn{3}{|c|}{ Temper Categories } & \multirow[b]{2}{*}{ B-H } & \multirow[b]{2}{*}{$\mathrm{N}$} \\
\hline & & G-B & G-H & G-B-H & & \\
\hline Plain & 27 & 3 & 35 & 1 & 5 & 71 \\
\hline Utility & 41 & 3 & 30 & 2 & 4 & 80 \\
\hline Fine & 8 & - & 4 & - & - & 12 \\
\hline Totals & 76 & 6 & 69 & 3 & 9 & 163 \\
\hline
\end{tabular}

$\mathrm{G}=$ grog; $\mathrm{G}-\mathrm{B}=$ grog-bone; $\mathrm{G}-\mathrm{H}=$ grog-hematite; $\mathrm{G}-\mathrm{B}-\mathrm{H}=$ grog-bone-hematite; $\mathrm{B}-\mathrm{H}=$ bone-hematite

The 92 sherds with decorative elements in the surface collection include sherds from utility wares ( 87 percent, sherds with wet paste decorations) and fine wares (13 percent, sherds with trailed or engraved decorative elements) (see Table 1). Almost the same proportion of utility ware and fine ware sherds were documented in Perttula and Stingley (2017) from the Walnut Branch site. 
More than 86 percent of the utility ware sherds in the 2018 surface collection from the Walnut Branch site have brushed decorative elements, or brushed decorative elements in combination with incised lines, applique, or punctations (Table 2). Most of these have parallel brushed marks or parallel brushed-incised marks and lines on the vessel body and rims with horizontal brushing from Bullard Brushed vessels (Figure 2a-c). One sherd is from a Spradley Brushed-Incised body sherd with parallel brushing marks and overlying opposed incised lines (Figure 3a). The one brushed-punctated sherd in the Walnut Branch site assemblage has vertical brushing marks and a vertical tool punctated row pushed through the brushing (Figure 3b).

Table 2. Decorative methods and elements in the utility ware and fine ware sherds in the 2018 surface collection at the Walnut Branch site.

\begin{tabular}{llll}
\hline Decorative method and elements & Rim & Body & N
\end{tabular}

\section{$\underline{\text { Utility ware }}$}

\section{Brushed}

horizontal brushed marks

overlapping brushed marks

parallel brushed marks

$\begin{array}{lll}1 & - & 1 \\ - & 2 & 2 \\ - & 40 & 4 \\ & & \\ - & 1 & 1\end{array}$

Brushed-Appliqued-Incised

parallel brushed marks-straight appliqued fillet-

parallel incised lines overlying brushed marks

\section{Brushed-Incised}

diagonal brushed-incised marks and lines

opposed brushed-incised marks and lines

parallel brushed-incised marks and lines

parallel brushed marks and overlying opposed incised

lines

Brushed-Incised-Punctated

diagonal brushed-incised marks and lines-fingernail

punctated row below the lip

\section{Brushed-Punctated}

vertical brushed marks-vertical tool punctated row

$-$

$-$

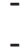

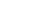

through the brushing

\section{Grooved}

horizontal grooved lines

parallel grooved lines

\section{Grooved-Punctated}

\section{Incised}

opposed incised lines parallel incised lines

straight incised line

$\begin{array}{lll}- & 1 & 1 \\ - & 2 & 2 \\ - & 1 & 1\end{array}$


Table 2. Decorative methods and elements in the utility ware and fine ware sherds in the 2018 surface collection at the Walnut Branch site, cont.

\begin{tabular}{llll}
\hline Decorative method and elements & Rim & Body & $\mathrm{N}$ \\
\hline $\begin{array}{l}\text { Incised-Punctated } \\
\text { straight incised line-adjacent tool punctated row }\end{array}$ & - & 1 & 1 \\
$\begin{array}{l}\text { Punctated } \\
\text { tool punctated row beneath the lip } \\
\text { tool punctated rows }\end{array}$ & 1 & - & 1 \\
\end{tabular}

\section{Fine ware}

\section{Engraved}

closely-spaced curvilinear engraved lines curvilinear engraved lines, one with tick marks horizontal engraved lines with excised tick marks horizontal-diagonal engraved lines opposed curvilinear engraved lines, two with excised tick marks

\section{Engraved-Brushed}

curvilinear engraved lines with excised pendant triangles-horizontal brushed body

horizontal-circular engraved lines with excised tick marks-horizontal brushed body horizontal-vertical engraved lines-excised tick markshorizontal brushed body

\section{Engraved-Punctated}

diagonal engraved line-excised pendant triangles on horizontal engraved line-excised punctated row beneath the lip opposed curvilinear engraved lines-excised punctated row beneath the lip

Excised

excised punctated row beneath the lip

$\begin{array}{lll}- & 1 & 1 \\ - & 1 & 1 \\ - & 1 & 1 \\ - & 1 & 1 \\ - & 1 & 1\end{array}$

\section{Trailed}

curvilinear trailed lines 

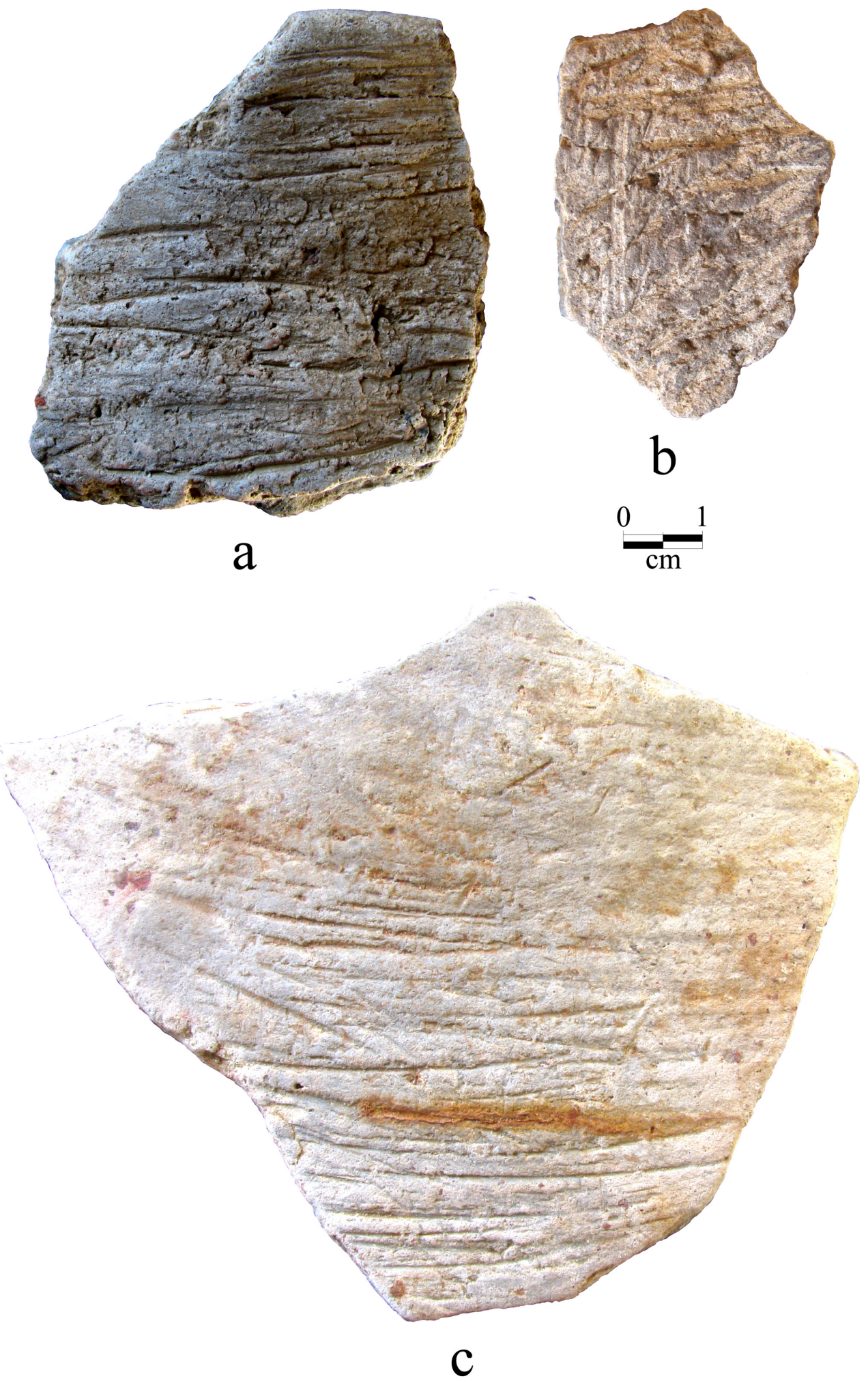

Figure 2. Brushed rim and body sherds from the Walnut Branch site. 

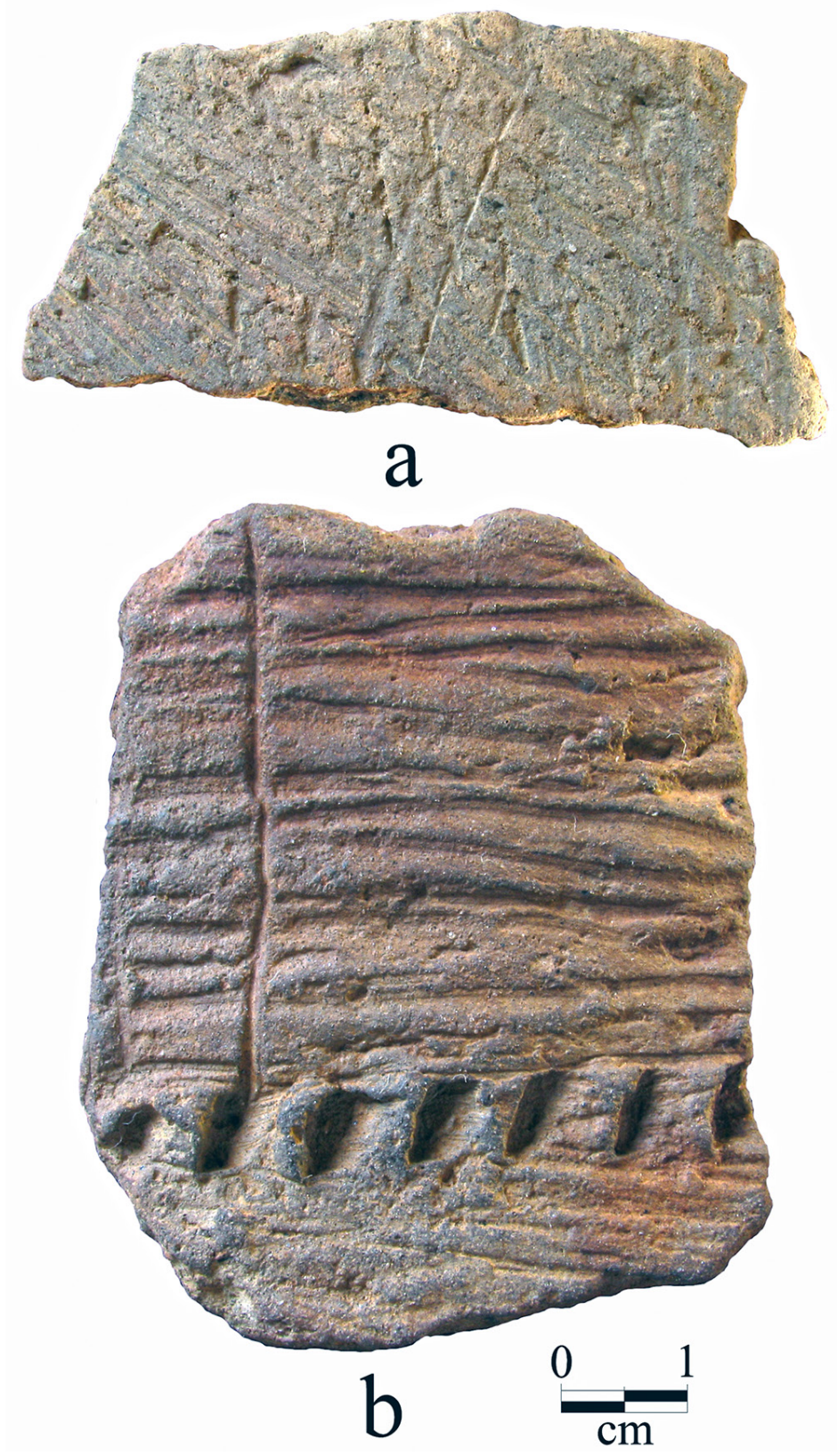

Figure 3. Brushed-incised (Spradley Brushed-Incised) and brushedpunctated sherds from the Walnut Branch site.

Sherds with grooved and grooved-punctated decorative elements comprise 5.0 percent of the utility wares in the 2018 surface collection assemblage. These sherds are from Allen phase Lindsey Grooved jars with horizontal and parallel grooved lines (Figure 4a-b). One rim sherd has horizontal grooved lines as well as a row of tool punctations beneath the lip (Figure 4c).

Only a few of the utility ware sherds have either incised (5.0 percent of the utility wares), incisedpunctated (1.3 percent), or punctated (2.5 percent) decorative elements (see Table 2 ). The incised sherds, likely from Maydelle Incised vessels, have opposed, parallel (Figure 5a), or straight-line elements. The one sherd with incised-punctated elements has a straight incised line adjacent to a row of tool punctations. The punctated sherds in the assemblage have tool punctated rows on the rim (Figure 5b) or body. 

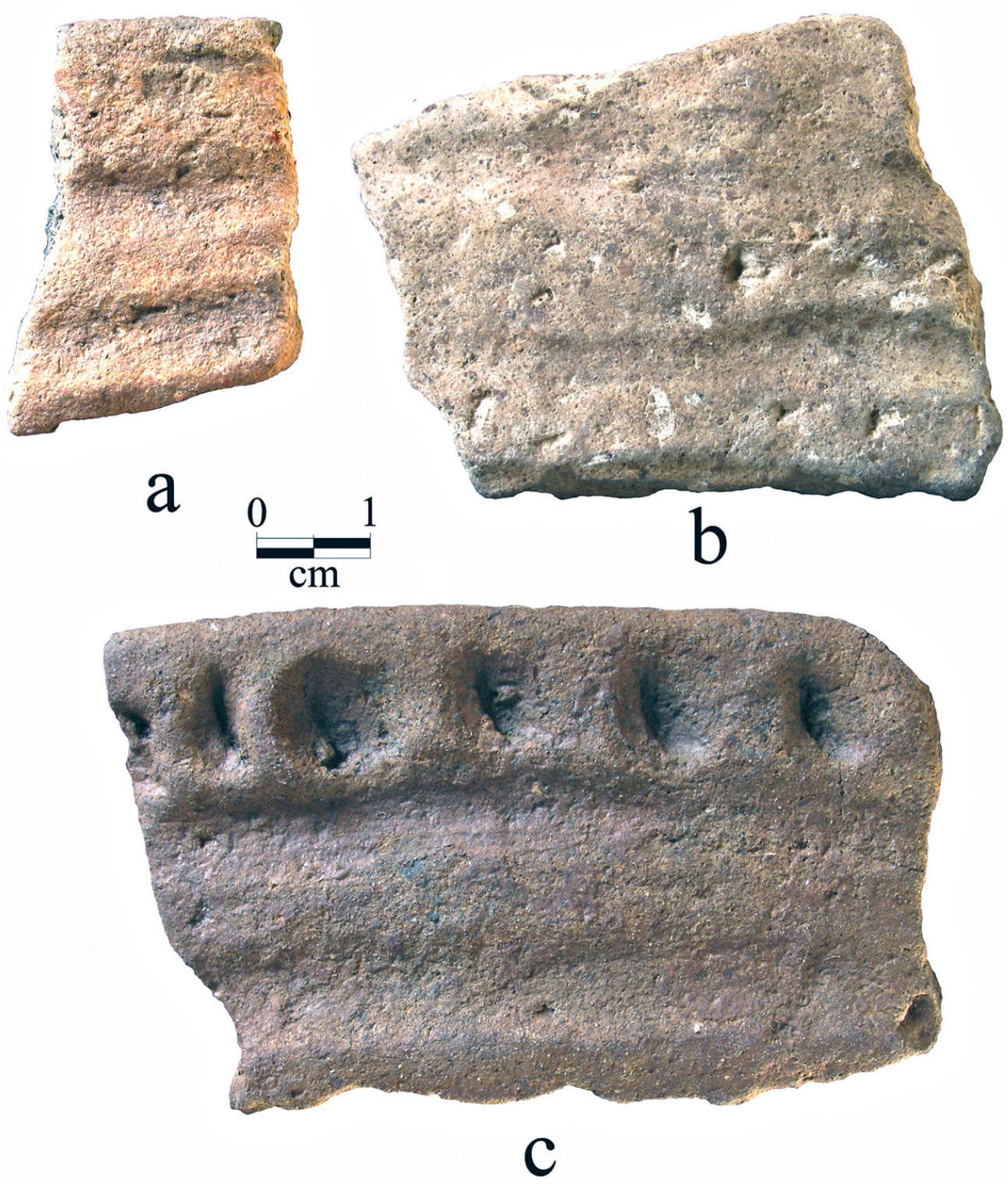

Figure 4. Lindsey Grooved rim and body sherds from the Walnut Branch site.

The majority of the engraved, engraved-brushed, engraved-punctated, and excised sherds in the 2018 surface collection are from several varieties of Patton Engraved defined in the upper and middle Neches River basin (Perttula 2011:Figure 6-66a-d). This includes a var. Freeman or var. Fair body sherd that has broadly-spaced horizontal engraved lines with excised tick marks (Figure 6a). Two others have curvilinear engraved lines, at least one of which has small excised tick marks (Figure 6b-c). Other engraved sherds in the collection have curvilinear or horizontal-diagonal elements (see Table 2). 


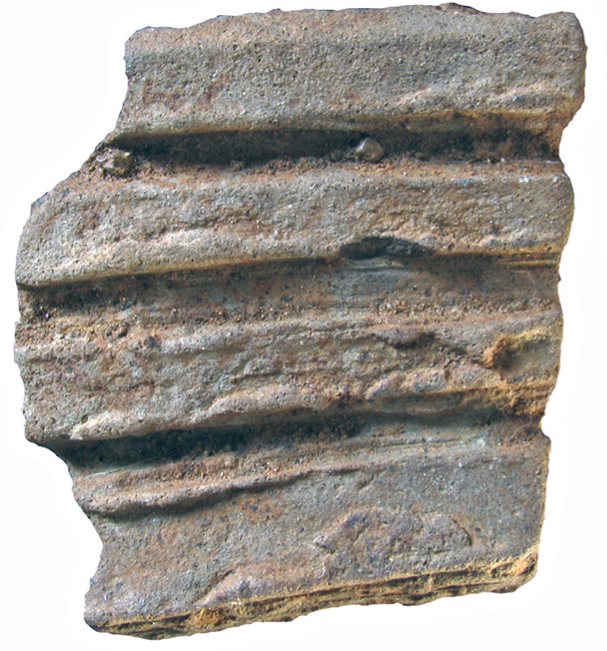

a

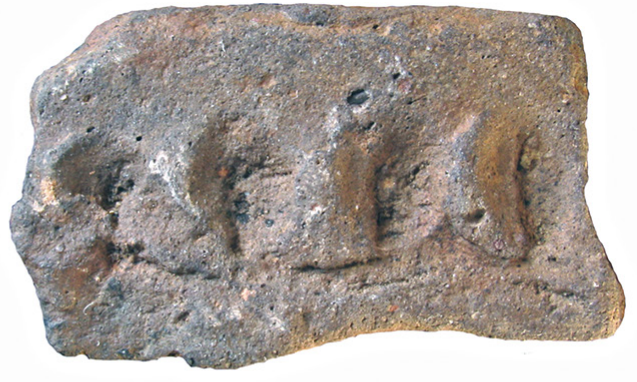

b

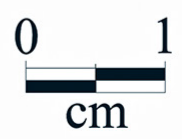

Figure 5. Incised and punctated sherds in the Walnut Branch site 2018 surface collection.

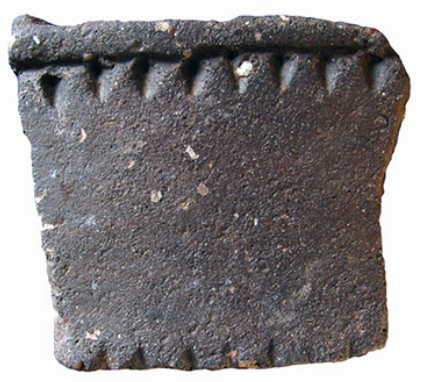

a

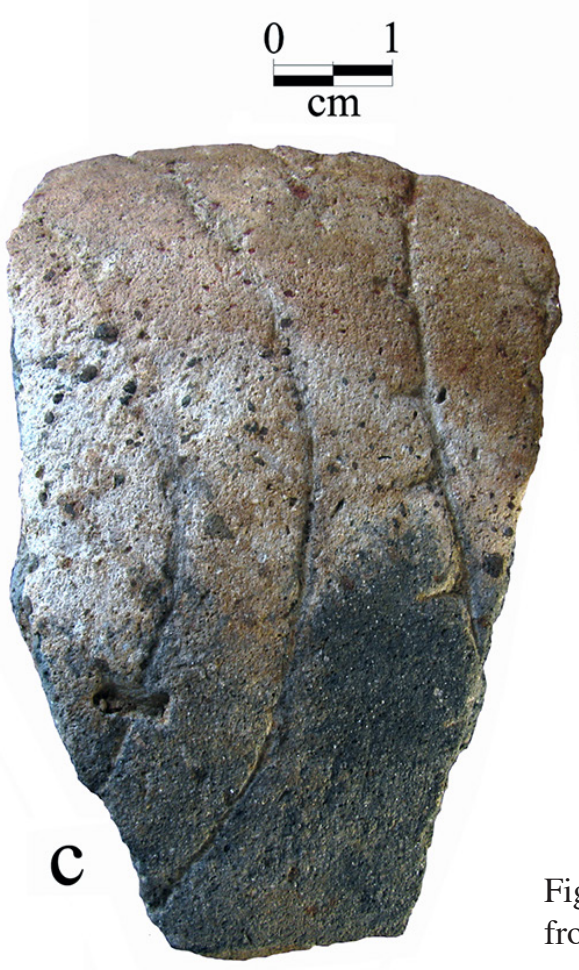

Figure 6. Patton Engraved, var. Freeman or var. Fair body sherds from the Walnut Branch site. 
Three Patton Engraved sherds are from carinated bowls with horizontal brushed bodies (see Table 2). The first two are likely from var. Fair vessels, the first with horizontal and circular engraved elements with large excised tick marks (Figure 7a), and the second with curvilinear engraved lines, one of which has large excised tick marks (Figure 7b). The last of the brushed Patton Engraved sherds, from a var. unspecified vessel, in the collection has horizontal and vertical engraved lines on the rim panel, with excised tick marks on the horizontal engraved line (Figure 7c).

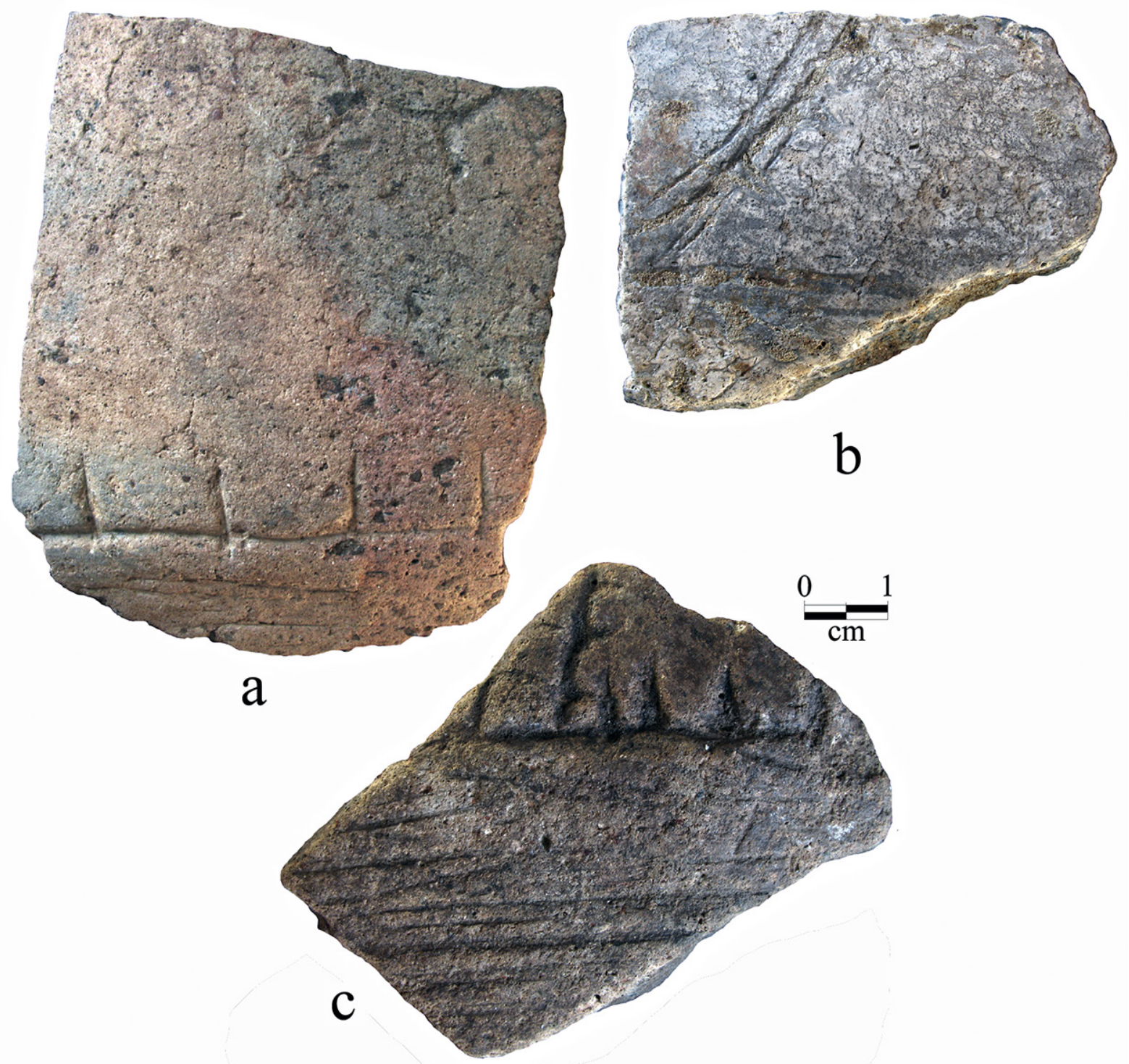

Figure 7. Patton Engraved carinated bowl sherds with brushed bodies from the Walnut Branch site.

The engraved-punctated rim sherds from the Walnut Branch site are distinctive because they do not have excised tick marks like the Patton Engraved vessel sherds do. Rather, they have a row of excised punctations just beneath the lip (Figure 8a-b), and on the rim are either opposed curvilinear engraved lines or a diagonal engraved line. On the latter (Figure 8b), the horizontal engraved line below the excised punctations has excised pendant triangle elements.

The last of the fine ware sherds is a trailed body sherd from a Keno Trailed bowl (see Table 2). The sherd has curvilinear trailed lines (Figure 9). 


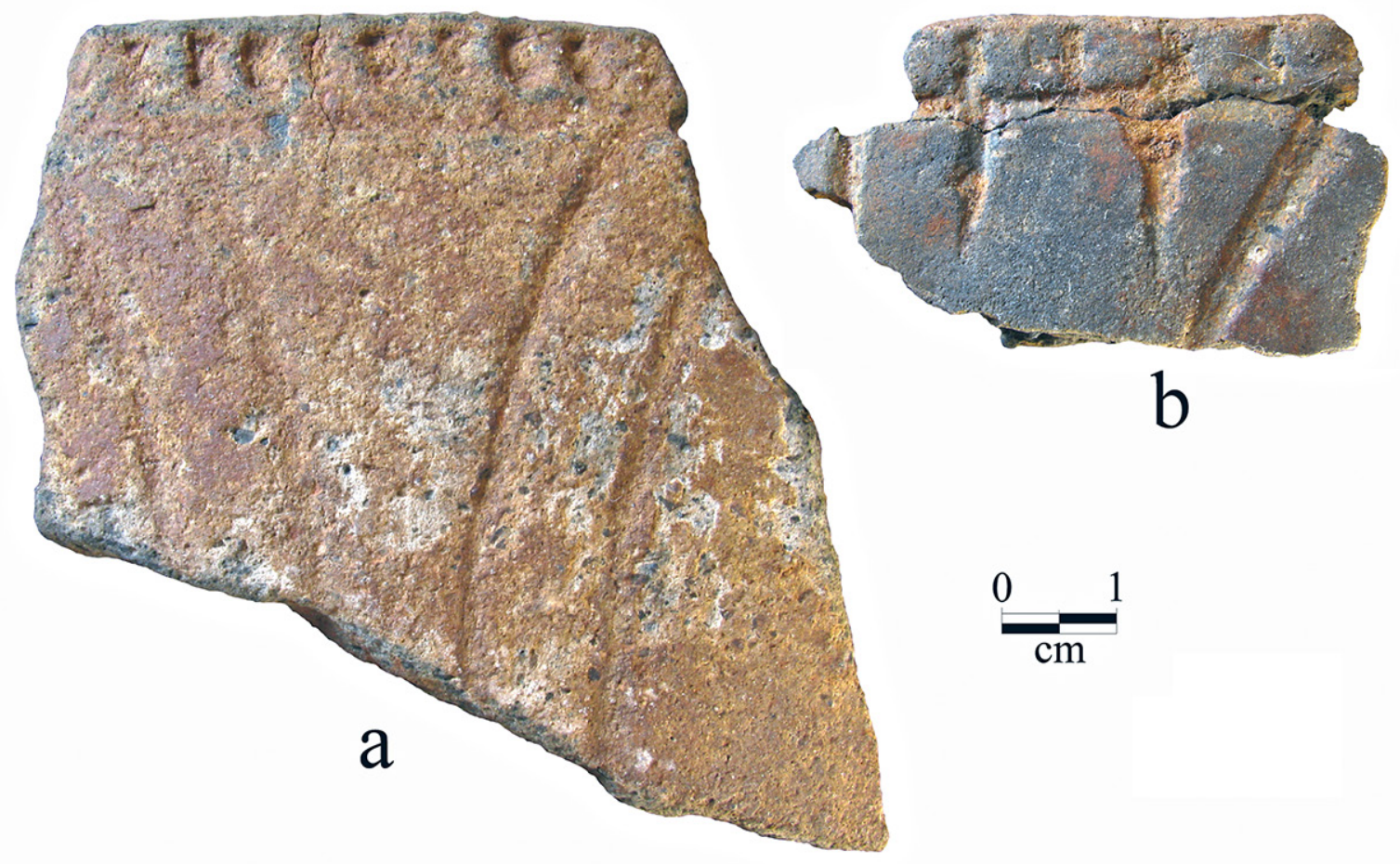

Figure 8. Engraved-punctated rim sherds from the Walnut Branch site.

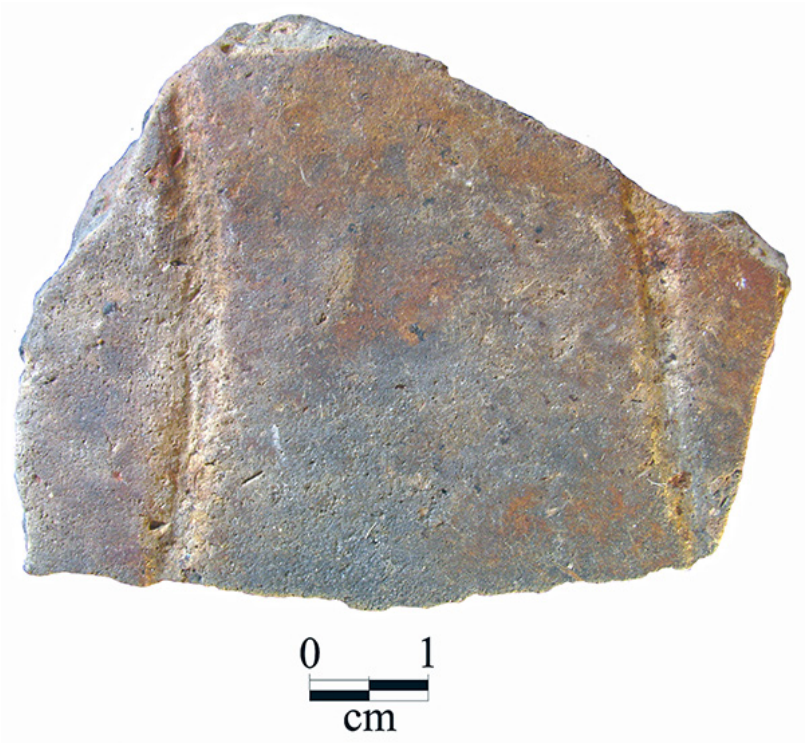

Figure 9. Keno Trailed body sherd from the Walnut Branch site.

\section{Ceramic Pipe Sherd}

Elbow pipe sherds are common in upper Neches River basin sites dating after ca. A.D. 1400. The one pipe sherd in the Walnut Branch site collection is a grog-tempered pipe bowl with two rows of circular punctations beneath the bowl lip (Figure 10). Such decorated pipes have been referred to as Neches pipes, and they have rows of punctations on the stem, heel, and bowl (see Jackson 1933:75, 1936:Plate 28; Perttula 2011:215 and Figure 24d). 


\section{Chipped Stone Flake Tool}

The one chipped stone tool in the surface collection is a unilateral flake tool, perhaps a unifacial scraper, of gray chert, with a rough limestone cortex (Figure 11). The used/retouched edge is $29.0 \mathrm{~mm}$ in length.

\section{Summary and Conclusions}

The Walnut Branch site (41CE47) in the Box's Creek drainage of the Neches River basin is a Historic Caddo period Allen phase settlement in the East Texas Pineywoods. Previous investigations at the site, including an intensive shovel testing effort in 2017 (Perttula and Stingley 2017), recovered a large assemblage of cultural materials, particularly ceramic vessel sherds $(n=554)$, ceramic elbow pipe sherds, clay coils, burned clay pieces, chipped stone tools, lithic debris, ground stone tools and red ochre, a lead ball, wood charcoal and nutshells, and a few animal bones. In 2018, another 165 artifacts from the site were surface-collected from several areas, especially along the Walnut Branch stream bed.

The additional ceramic vessel sherds from the Walnut Branch site collected in 2018 provide more detail on the character of the ceramic vessel sherd assemblage at this Neche cluster Allen phase component. The sherds are from vessels almost exclusively tempered with grog, although many of the sherds are from vessels tempered with both grog and crushed pieces of hematite. The use of bone temper is only moderate (less than 13 percent of the sherd assemblage).

The decorated sherds comprise 56 percent of the combined ceramic vessel sherd assemblage at the Walnut Branch site (Table 3). Almost 88 percent of the decorated sherds are from utility ware jars, and almost 70 percent of the sherds are from vessels with brushed decorative elements (sometimes in combination with appliqued, incised, or punctated elements). Most of these sherds are from Bullard Brushed vessels. Other utility ware types represented in the assemblage include Lindsey Grooved, Killough Pinched, Maydelle Incised, and Spradley Brushed-Incised, but they are not common compared to the many brushed vessel sherds. A few other sherds have punctated decorative elements, but they have not been identified to a type, other than labeled as miscellaneous utility pottery (see Suhm and Jelks 1962:Plate 79). 
Table 3. Summary of the recovered ceramic vessel sherd assemblage from the 1969, 2017 and 2018 investigations at the Walnut Branch site.

Total No. of Sherds: 717

Total No. of Plain Sherds: 313

Total No. of Decorated Sherds: 404

Plain to Decorated Sherd Ratio: 0.77

\begin{tabular}{lll}
\hline Decorative Method & No. of Sherds & Percent of Assemblage \\
\hline
\end{tabular}

\section{$\underline{\text { Utility Ware }}$}

$\begin{array}{llc}\text { Appliqued } & 1 & 0.2 \\ \text { Brushed } & 165 & 40.8 \\ \text { Brushed-Appliqued } & 1 & 0.2 \\ \text { Brushed-Incised } & 108 & 26.7 \\ \text { Brushed-Incised-Appliqued } & 2 & 0.5 \\ \text { Brushed-Incised-Punctated } & 1 & 0.2 \\ \text { Brushed-Punctated } & 4 & 1.0 \\ \text { Grooved } & 9 & 2.2 \\ \text { Grooved-Brushed } & 1 & 0.2 \\ \text { Grooved-Punctated } & 1 & 0.2 \\ \text { Incised } & 39 & 9.6 \\ \text { Incised-Punctated } & 4 & 1.0 \\ \text { Pinched } & 4 & 1.0 \\ \text { Punctated } & 15 & 3.5 \\ & & \\ \text { Subtotal } & 355 & 87.9\end{array}$

\section{Fine Ware}

\begin{tabular}{llc} 
Engraved & 40 & 9.9 \\
Engraved-Brushed & 4 & 1.0 \\
Engraved-Excised Punctated & 2 & 0.5 \\
Excised Punctated & 1 & 0.2 \\
Trailed & 2 & 0.5 \\
Subtotal & 49 & 12.1 \\
\hline Totals & 404 & 100.0
\end{tabular}

The fine ware sherds at the Walnut Branch site include sherds from Patton Engraved (several varieties) and Keno Trailed carinated bowls and bowls (see Table 3). There are also two distinctive engraved rim sherds in the collection that have a row of excised punctations beneath the lips of two different vessels . 


\section{Acknowledgments}

Lance Trask prepared the figures for this article.

\section{References Cited}

Jackson, A. T.

1933 Some Pipes of East Texas. Bulletin of the Texas Archeological and Paleontological Society 5:69-86.

1936 A Perpetual Fire Site. Bulletin of the Texas Archeological and Paleontological Society 8:134-174.

Perttula, T. K.

2011 The Ceramic Artifacts from the Lang Pasture Site (41AN38) and the Place of the Site within an Upper Neches River Basin Caddo Ceramic Tradition. In Archeological Investigations at the Lang Pasture Site (41AN38) in the Upper Neches River Basin of East Texas, assembled and edited by T. K. Perttula, D. B. Kelley, and R. A. Ricklis, pp. 145-320. Archeological Studies Program Report No. 129, Texas Department of Transportation, Environmental Affairs Division, Austin.

Perttula, T. K. and K. Stingley

2017 Archaeological Investigations at the Walnut Branch (41CE47), Ross I (41CE485), and Ross II (41CE486) Sites, Cherokee County, Texas. Journal of Northeast Texas Archaeology 76:31-70.

Suhm, D. A. and E. B. Jelks (editors)

1962 Handbook of Texas Archeology: Type Descriptions. Special Publication No. 1, Texas Archeological Society, and Bulletin No. 4, Texas Memorial Museum, Austin. 